\title{
Integrated farming approach for runoff recycling systems in humid plateau areas of eastern India
}

\author{
R.C. Srivastava*, R.B. Singhandhupe, R.K. Mohanty \\ Water Technology Centre for Eastern Region, Bhubaneswar, Orissa 751 023, India
}

Accepted 3 July 2003

\begin{abstract}
Regions having undulating terrain are predominantly rainfed and have a poor productivity level. As the traditional irrigation systems, viz. canal irrigation and tubewell irrigation are not feasible due to topographical, geological and hydrological constraints, rainwater harvesting has been found to have potential of being an irrigation water resource which can provide full irrigation in conjunction with rainfall to a transplanted rice based two crop rotation. Utilization of stored water in both monsoon and post-monsoon season crops increases the efficiency of the system which is evident from higher water yield-storage capacity ratio of 1.75 . The evaluation of a rain water harvesting system has shown that integrated farming approach of utilizing the system enhances the economics of the system. While the B-C ratio with only crop was 1.89 , it increased to 2.27 if horticultural crops are taken on the embankment of the tank. It further increased to 2.80 when fish culture is taken up in the stored water. There is possibility of its increasing to more than 3.0 if duckery is also taken up. Extrapolating these results, benefit cost analysis has been done for other two site conditions where the seepage loss is between 6 and $10 \mathrm{~mm} /$ day and seepage loss is more than $10 \mathrm{~mm} /$ day and therefore lining is required. (c) 2003 Elsevier B.V. All rights reserved.
\end{abstract}

Keywords: Runoff recycling; Integrated farming; Water yield-storage capacity ratio; Benefit cost ratio

\section{Introduction}

Low and unstable yields and resource poor farmers characterize the rainfed areas of the plateau region of eastern India, which is classified as Agro Ecological Region No. 12 by Sehgal et al. (1992). This region encompasses states of Chhattisgarh, Jharkhand, hilly parts of northern Andhra Pradesh, western and north-western Orissa and southern part of West Bengal. The climatic water balance of the region shows that water deficit is prevalent from

\footnotetext{
* Corresponding author. Tel.: +91-674-2300010; fax: +91-674-2301651.

E-mail address: ramesh_wtcer@yahoo.com (R.C. Srivastava).
} 
November to May in almost all locations (WTCER, 2001). The irrigation development is quite low with irrigated area being just $10.05 \%$ in Jharkhand, $22.46 \%$ in Chhattisgarh and $35.13 \%$ in Orissa. The cropping intensity in two states, Jharkhand and Chhattisgarh, which are totally in this eco-region, is just 123.8 and $113.6 \%$. Due to these factors, a high percent of population $(>40 \%)$ is below poverty line and in absence of employment opportunities, migration of laborers take place creating serious socio-economic consequences. Study of two villages of Kalahandi district of Orissa showed that lower productivity has resulted in cultivation of marginal lands. The proportion of marginal lands in total cultivated area is as high as $70 \%$, which contributes huge amount of runoff and sediment aggravating land resource management scenario. Surprisingly, even with cultivation of these lands, deficit in nutritional terms is very high. In one village, the deficiency for energy is $58.9 \%$, for protein $34.2 \%$, for calcium $53.8 \%$, for iron $40.0 \%$, for cereal $59.7 \%$, for pulses $48.4 \%$, for vegetables $90 \%$, and for oil and fats $77.8 \%$. This indicates the malnutrition levels of the population (WTCER, 2001). These deficits have been estimated on the basis of assumption that all the production is consumed locally while it is not the case as a part of produce is sold to meet the cash requirement.

Providing irrigation is a major tool for alleviating the poverty by increasing and stabilizing productivity as well as retiring marginal lands. As the traditional irrigation systems, viz. canal irrigation and tubewell irrigation are not feasible due to topographical, geological and hydrological constraints, rainwater harvesting has been found to have potential of being an irrigation water resource which can provide full irrigation in conjunction with rainfall to a transplanted rice based two crop rotation (Bhatnagar et al., 1996; Srivastava and Panda, 1998; Srivastava, 1996a,b, 2001). Figs. 1 and 2 presents the climatic balance under various rain water management levels. It is evident from the figures that if the rainfall would have uniform distribution, it was sufficient to meet up the evaporative demand. However, the case not being so, if the runoff from a particular catchment area is used by storing it, the period for which the evaporative demand will be met will depend upon the catchment command area ratio (CCR). For CCR $=1.0$, the demand upto November can be met while with $\mathrm{CCR}=5.0$, the demand up to May can be met. Thus, there is potential of runoff

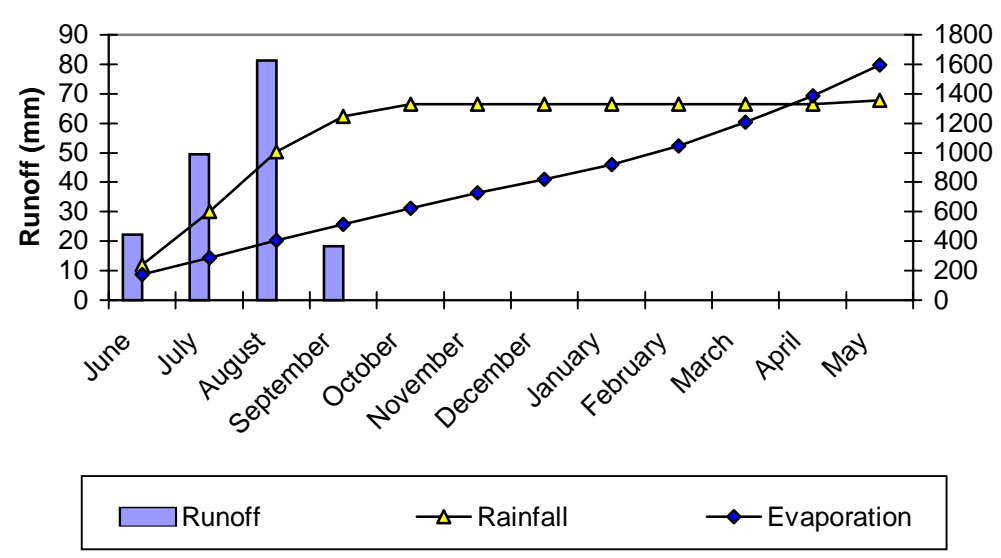

Fig. 1. Cumulative rainfall and open pan evaporation at 50\% probability. 


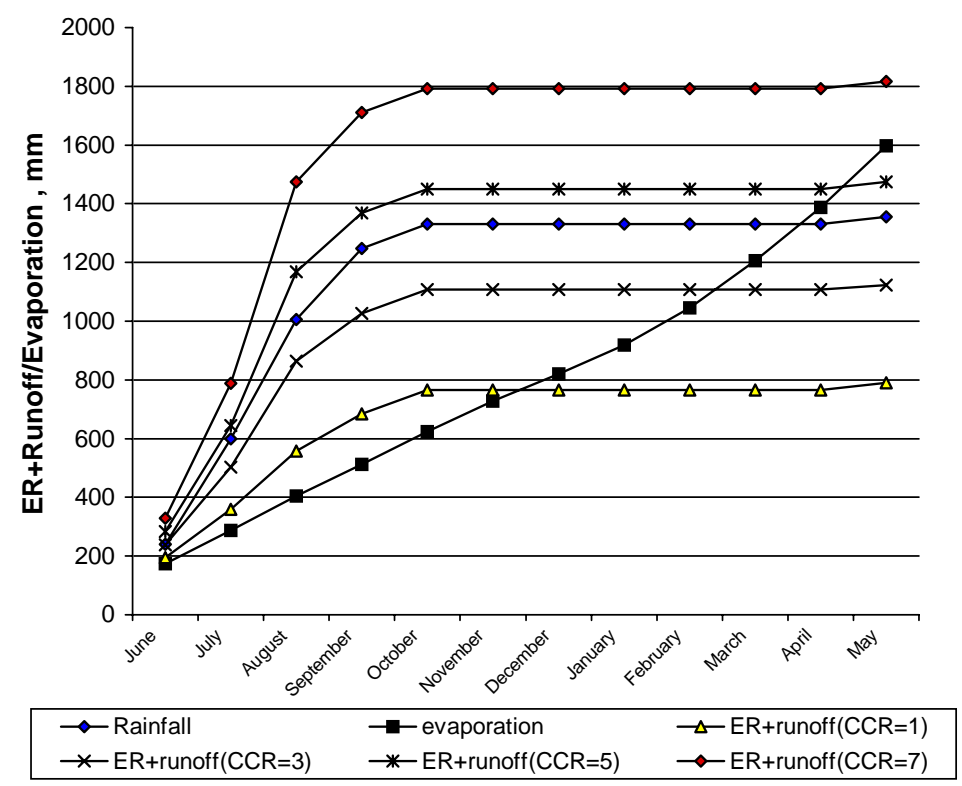

Fig. 2. Cumulative effective rainfall (ER) + runoff at different CCR and open pan evaporation at 50\% probability.

recycling based irrigation system meeting the evaporative demand of a two crop rotation with a particular catchment command area ratio.

With this in view, Srivastava (2001) developed a methodology for design of water harvesting system for high rainfall areas to irrigate transplanted rice based crop rotation. The methodology used was simultaneous simulation of water balance of tank and field. Using this methodology, design parameters of a water harvesting based irrigation system were developed which are presented in Table 1 . These parameters have been determined by simulation model to get the desired water/moisture regime at $80 \%$ exceedance probability

Table 1

Design parameters of runoff recycling systems under different conditions

\begin{tabular}{|c|c|c|c|c|}
\hline $\begin{array}{l}\text { Serial } \\
\text { number }\end{array}$ & Item & $\begin{array}{l}\text { For sites having } \\
\text { seepage loss } \\
<6 \mathrm{~mm} / \text { day }\end{array}$ & $\begin{array}{l}\text { For sites having } \\
\text { seepage loss }>6 \text { but } \\
\text { less than } 10 \mathrm{~mm} / \text { day }\end{array}$ & $\begin{array}{l}\text { For sites having seepage } \\
\text { loss }>10 \mathrm{~mm} / \text { day, i.e. } \\
\text { lined tanks }\end{array}$ \\
\hline 1 & $\begin{array}{l}\text { Tank capacity per hectare } \\
\text { command area }\end{array}$ & $1750 \mathrm{~m}^{3}$ & $2500 \mathrm{~m}^{3}$ & 1650 \\
\hline 2 & $\begin{array}{l}\text { Catchment command area } \\
\text { ratio }\end{array}$ & $\geq 3.0$ & $\geq 5.0$ & $\geq 3.0$ \\
\hline 3 & Rice variety & \multicolumn{3}{|c|}{ Short (110-115 days) or medium duration (130-135 days) } \\
\hline 4 & Post-monsoon crop & \multicolumn{3}{|c|}{ Low duty crop in full command or higher duty in partial command } \\
\hline 5 & Size of the system & Convey & Ince efficiency should & ot be less than $80 \%$ \\
\hline 6 & $\begin{array}{l}\text { Total runoff water captured per } \\
\text { unit command area at } 80 \% \\
\text { probability (runoff stored } \\
+ \text { seepage loss from tank and } \\
\text { water stored in fields) }\end{array}$ & $6062 \mathrm{~m}^{3}$ & $6753 \mathrm{~m}^{3}$ & $4687 \mathrm{~m}^{3}$ \\
\hline
\end{tabular}


levels. The model was run for different seepage rates and the parameters changed when seepage rate increased $6 \mathrm{~mm} /$ day. It again changed when seepage rate exceeded $10 \mathrm{~mm} /$ day. Due to this, the parameters have been given at these ranges. Although the theoretical design parameters were developed, its hydrological and economic evaluation was necessary before it is recommended for large scale adoption on farmers' field. With this in view, an evaluation study was undertaken at Research Farm of Water Technology Centre for Eastern Region, Bhubaneswar (Orissa), India for three crop seasons: 1998-1999, 1999-2000 and 2000-2001. The evaluation of the system was done with an integrated farming approach consisting of fishery, duckery, and horticulture on embankment along with a crop in the command area. This article presents the results of this evaluation.

\section{Material and methods}

\subsection{Design of the system}

The system was designed with a catchment area of 3 ha and command area of 0.95 ha. The tank capacity was $1468 \mathrm{~m}^{3}$. The sketch diagram of the system is presented in Fig. 3 and other details are given in Table 2. The land use of the catchment area was cultivated terrace at a slope of $2-3 \%$. The command area was also terraced land with a slope of $1-2 \%$. The tank has a hume pipe inlet and hume pipe outlet. A provision for surplus flow was made on inlet side to avoid the additional cost of a surplus weir. The tank was not lined as the seepage losses were found to be around $2 \mathrm{~mm} /$ day, which is within critical limit of $6 \mathrm{~mm}$ /day prescribed by Srivastava (2001).

The top layer $(0-15 \mathrm{~cm})$ of soil of the command area is sandy clay loam followed by sandy loam $(15-30 \mathrm{~cm})$, clay loam $(30-45,45-60$ and $60-90 \mathrm{~cm}$ depth) and the clay content in $0-90 \mathrm{~cm}$ depth varied from 21.0 to $36.5 \%$. The basic infiltration rate of the soil is $1.64 \times$ $10^{-5} \mathrm{~m} / \mathrm{s}$. The available water in top soil layer is $0.108 \mathrm{~cm}^{3} / \mathrm{cm}^{3}$ and it increases with depth,

Table 2

Runoff recycling system at a glance

\begin{tabular}{rll}
\hline Serial number & Item & Quantity \\
\hline 1 & Catchment area & 3 ha \\
2 & Command area & 0.95 ha \\
3 & Tank capacity & $1468 \mathrm{~m}^{3}$ \\
4 & Water area & $900 \mathrm{~m}^{2}$ \\
5 & Area occupied & 0.13 ha, i.e. $15 \%$ of command area \\
6 & Lining material & No lining as seepage was 2 mm/day \\
7 & Total investment & Rs. $48,000 /-$ \\
8 & Crop rotation & Rice-groundnut/mustard/watermelon \\
9 & Fishes & Indian major carps and prawn \\
10 & Horticultural crops & Papaya: 140 plants; banana: 64 plants \\
11 & Average water yield in 3 years & $2574 \mathrm{~m}^{3}$ \\
12 & Water yield/storage capacity ratio & 1.75 \\
\hline
\end{tabular}




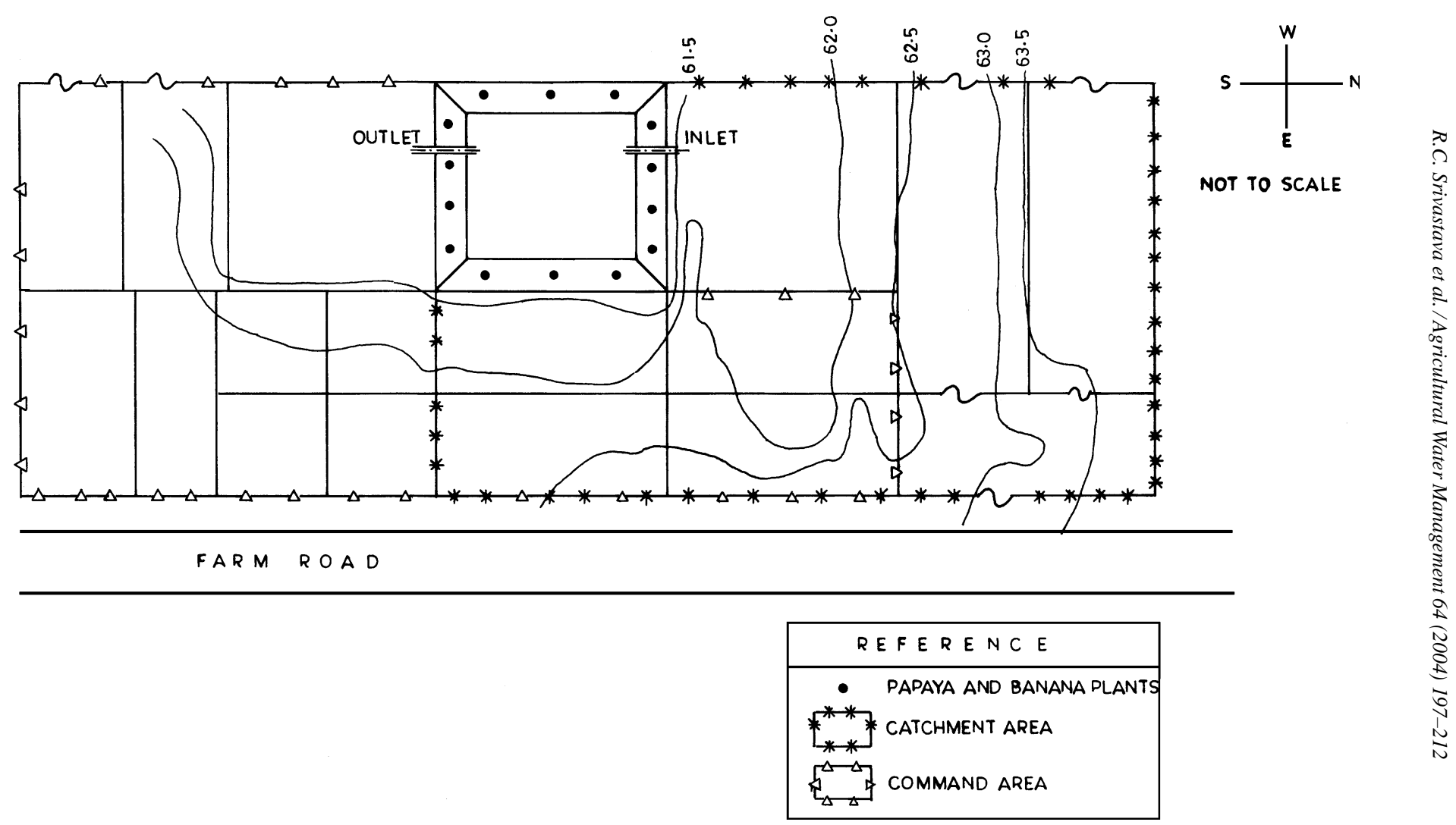

Fig. 3. Schematic diagram of runoff recycling system. 
the maximum being $0.138 \mathrm{~cm}^{3} / \mathrm{cm}^{3}$ in $45-60 \mathrm{~cm}$ soil depth. The soil is acidic in reaction with $\mathrm{pH}$ ranges from 5.80 in $0-15 \mathrm{~cm}$ soil depth to maximum of 6.33 in $45-60 \mathrm{~cm}$ depth. The corresponding values of electrical conductivity was $71.9 \mu \mathrm{S}(0.0719 \mathrm{ds} / \mathrm{m})$ in top layer to $51.6 \mu \mathrm{S}(0.0516 \mathrm{ds} / \mathrm{m})$ in $45-60 \mathrm{~cm}$ soil depth. The soil is low in organic carbon content. It decreases with increasing soil depth and is ranging from $4.6 \mathrm{~g} / \mathrm{kg}$ soil in top layer to $3.1 \mathrm{~g} / \mathrm{kg}$ in $60-90 \mathrm{~cm}$ soil depth. With regards to availability of plant nutrients, soil is low in available nitrogen, medium in available phosphorus and potassium (Singh et al., 2000).

\subsection{Water balance of the pond and command area}

The water level in the pond and amount of water pumped during different months were monitored for determining the water availability and water used. The pump had one water meter connected on the delivery side to measure the water. For command area, the depth of water in the rice field during monsoon season was monitored. For post-monsoon season crops, the soil moisture was monitored.

\subsection{Performance of crop, horticultural crops and fish}

The monsoon season crop in all the 3 years was transplanted rice but the post-monsoon crop was a combination of crops. In first and second year, it was groundnut and mustard, and in third year it was groundnut and watermelon. The crops were changed due to some practical problems as well as with a view of evaluating a mosaic of crops in the command area.

Two rows of papaya were planted on the embankment at a row spacing of $2 \mathrm{~m}$ and plant spacing of $1.80 \mathrm{~m}$. Banana was planted on inside slope making a triangle with inner papaya row in September 1999. However, almost all plants were uprooted in the super cyclone of 1999 and replanting was done in monsoon of 2000 and the yield of these plants could be recorded only during 2000-2001 season.

For fish, fry (36 mm average length and $0.97 \mathrm{~g}$ mean body weight) of Indian major Carps, i.e. Labeo rohita, Cirrhinus mrigala, and Catla catla were stocked at the rate of $30,000 \mathrm{ha}^{-1}$ water area with a species composition of 30:40:30, respectively. In addition, Macrobrachium rosenbergii prawn postlarvae seed of $\mathrm{PL}_{13}$ at the rate of $3000 \mathrm{ha}^{-1}$ were also stocked in 1998-1999 and 2000-2001. Due to non-availability of seed, the prawn could not be stocked in 1999-2000. Fish growth parameters, condition factor, apparent feed conversion ratio were estimated using standard methods (Mohanty, 1999) along with soil and water quality parameters (APHA, 1989; Biswas, 1993). To study the degree of satiation and index of electivity of cultured species (Spataru and Gophen, 1986), six fishes of each species were sacrificed twice; once at 30th day of rearing and again after harvesting on 181st day during first and second crop, respectively. Culture duration was for 180 days. Cow dung was applied at the rate of $5000 \mathrm{~kg} / \mathrm{ha}$ as a basal dose prior to stocking. No water treatment (except liming at the rate of $150 \mathrm{~kg} / \mathrm{ha}$ at fortnightly interval) and fertilizer application was made due to entry of runoff water from one end and discharge from other end for irrigation, which was a regular practice. Low cost supplemental feed (rice bran and groundnut oil cake, 1:1) was given at the rate of 10, 8, 6, 5, 4 and $3 \%$ of mean body weight for $1 \mathrm{st}, 2 \mathrm{nd}$, 3rd, 4th, 5th, and 6th month, respectively. Primary productivity and plankton estimation was done as 
described by Mohanty (2000). No return from duckery could be obtained as all the ducks were stolen during nights.

\subsection{Economics of the system and sensitivity analysis}

The economics of the system was calculated on the basis of gross benefits obtained from different activities additional cost incurred to conduct those activities and cost of the system. Benefit cost ratio was estimated on the basis of annual cost of the system and annual benefit. The expected return from the land occupied by the system under rainfed condition was also accounted for estimation of the cost. The items considered for cost estimation were: (i) annual cost of pond (depreciation, interest on investment and maintenance); (ii) cost of pumping of water; (iii) additional cost of rice cultivation; (iv) cost of cultivation of post-monsoon season crop; (v) annual cost of cultivation of horticultural crops; (vi) annual cost of fish culture; and (vii) return from land occupied by tank. The benefits considered are: (i) increase in rice yields; (ii) yield of post-monsoon crops; (iii) yield of horticultural crops; and (iv) yield of fish and prawn. Although duckery could not be practiced, an assumed value has been included to show the benefits. The prices have been taken on the basis of the prevailing rates. The cost of water pumped has been estimated on the basis of prevailing hiring charges in the area. The additional cost of rice cultivation has been taken as cost of nursery raising plus transplanting minus saving on account of less seed requirement and cost of weeding. The cost of cultivation of horticultural crops and fish culture has been taken on the basis of real cost involved. The return from land occupied by the tank has been taken on the basis of return under rainfed conditions.

To assess the sensitivity of the system, the economic analysis was done for all the three conditions: (i) for sites, where seepage loss is less than $6 \mathrm{~mm} /$ day; (ii) for sites, where seepage loss is more than $6 \mathrm{~mm} /$ day but less than $10 \mathrm{~mm} /$ day; and (iii) for site where seepage loss is excessive and lining is essential. The field results of the first conditions were extrapolated to get results of other two conditions.

\section{Results and discussion}

\subsection{Water balance of pond and command area}

Fig. 4 presents the water balance of all the 3 years. In 1998-1999, tank construction was completed by mid July and the water started flowing from 1st August. The tank got full by mid August. In 1999-2000 and 2000-2001, the ponds got filled by 1st week of August itself. The water was utilized for irrigating paddy but this is not evident from figures as the data has been presented on fortnightly basis and the water got replenished by subsequent runoff events. In first 2 years, the tank remained full up to December and then water level started declining, but in 2000-2001 year, the monsoon withdrew earlier and tank water level started declining from October onward itself due to water use, evaporation and seepage loss. Further there was some replenishment in 1999-2000 and 2000-2001 due to unseasonal rains and the total volume of water at the end of the year remained almost same. This indicate that the tanks are very useful in leveling out the rainfall aberrations. Table 3 presents the 


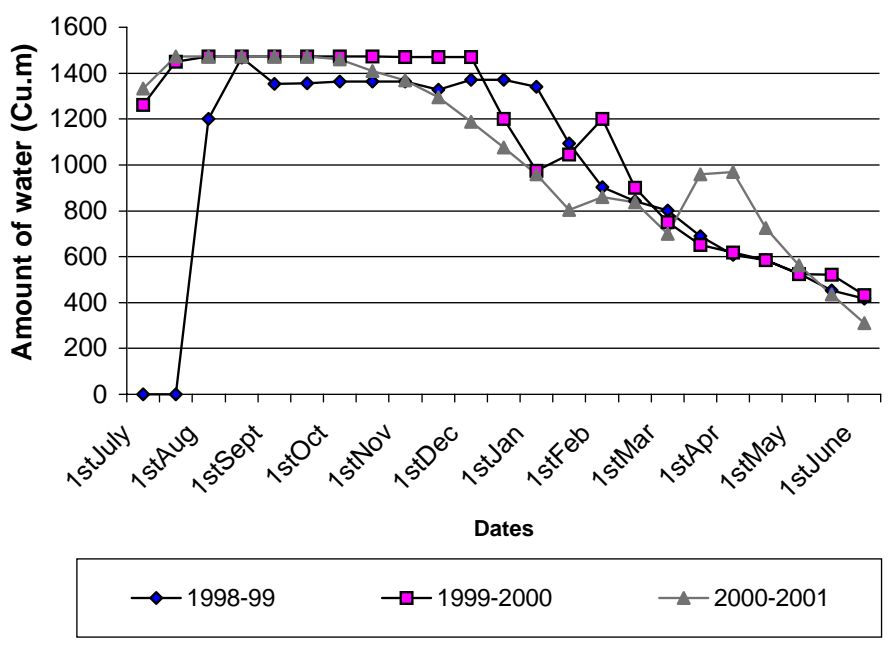

Fig. 4. Tank water balance of 3 years.

amount of water pumped from the tank which shows that water was pumped out both in monsoon season to take care of transplanted paddy crop and post-monsoon season for succeeding crops of groundnut and other crops. Thus, it can be said that pond could provide irrigation water both during monsoon as well as post-monsoon season for successful crop growth. The total amount of water available varied from 2026 to $3309 \mathrm{~m}^{3}$. The average water yield/storage capacity which explains the total water availability from storage tank per unit storage capacity is 1.75 for 3 years. With proper selection of catchment command area ratio, the water used has been replenished by subsequent storms both in monsoon as well as dry season. This reduces the cost of water significantly. This situation in high rainfall areas is different from semi arid conditions where this ratio is normally less than 1.0 which sometime makes water resource creation uneconomical. The average water pumped/storage capacity is 1.43 , which is less than the water yield/storage capacity but as the remaining water is used for fish culture and is important for duckery, it has economic value.

Table 3

Details about water pumped from tank

\begin{tabular}{|c|c|c|c|c|c|}
\hline $\begin{array}{l}\text { Serial } \\
\text { number }\end{array}$ & Item & 1998-1999 & 1999-2000 & 2000-2001 & Average \\
\hline 1 & $\begin{array}{l}\text { Amount of water pumped during } \\
\text { monsoon season }\left(\mathrm{m}^{3}\right)\end{array}$ & 915 & 1382 & 585 & 961 \\
\hline 2 & $\begin{array}{l}\text { Amount of water pumped during } \\
\text { post-monsoon season }\left(\mathrm{m}^{3}\right)\end{array}$ & 710 & 1310 & 1391 & 1137 \\
\hline 3 & $\begin{array}{l}\text { Amount of water available in tank } \\
\text { afterpost-monsoon crop }\left(\mathrm{m}^{3}\right)\end{array}$ & 401 & 617 & 410 & 476 \\
\hline 4 & Total water yield $\left(\mathrm{m}^{3}\right)$ & 2026 & 3309 & 2386 & 2574 \\
\hline 5 & Water yield/storage capacity ratio & 1.38 & 2.25 & 1.63 & 1.75 \\
\hline 6 & Water pumped/storage capacity ratio & 1.11 & 1.83 & 1.35 & 1.43 \\
\hline
\end{tabular}




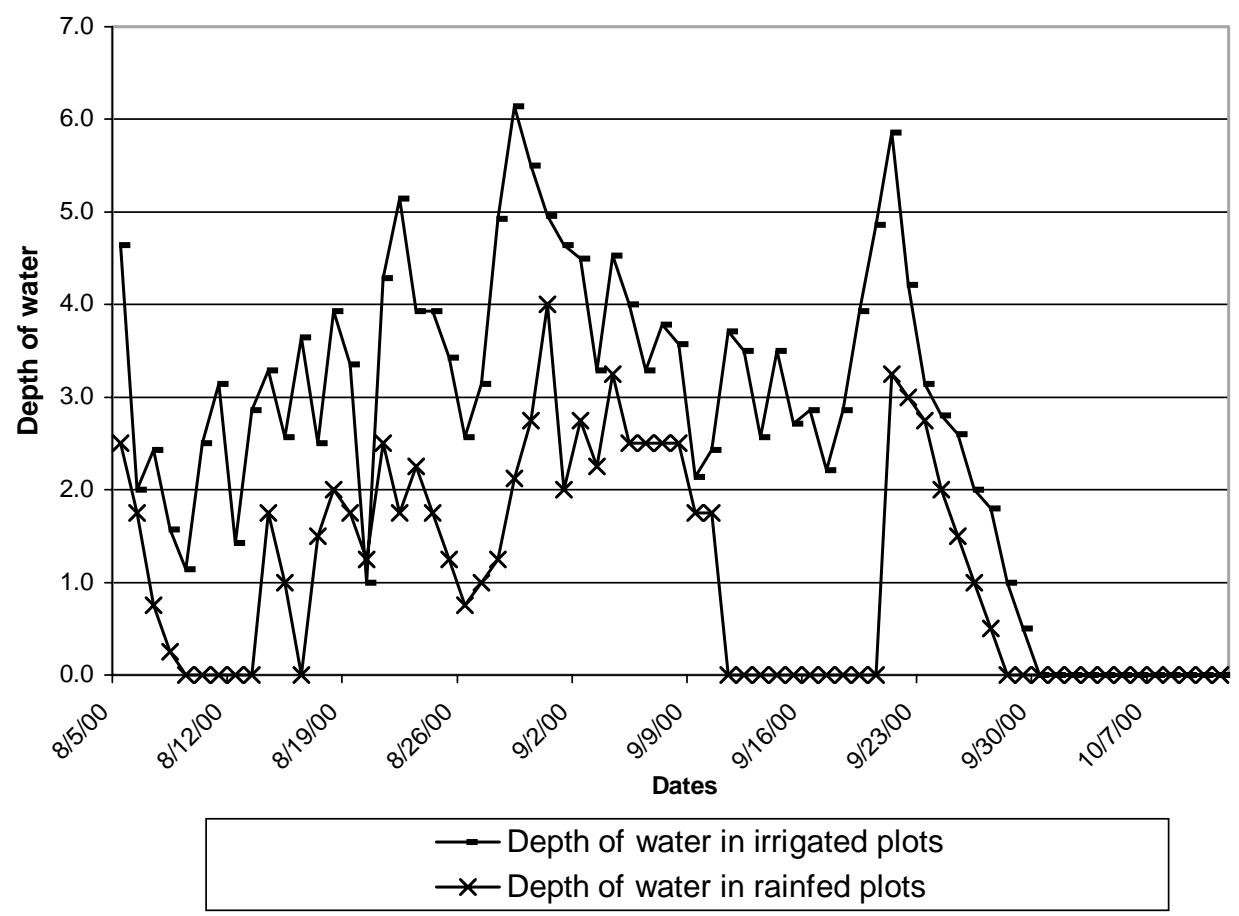

Fig. 5. Depth of ponding in irrigated and rainfed rice plots (monsoon season-2000).

The depth of ponding in irrigated and unirrigated paddy plots for 2000-2001 is presented in Fig. 5. It is evident from figure that for rainfed rice, the depth of water was below $2.5 \mathrm{~cm}$ for most of the time and crop also faced moisture stress for 4 days in one spell and for 10 days in another spell. The second spell coincided with reproductive phase which may be responsible for yield reduction. Similar pattern was also observed in other years also. For irrigated rice, there was no water shortage with depth of ponding being above saturation from transplanting to physiological maturity stage. Similar results were found for other years also. During post-monsoon season also, the timely irrigation maintained the moisture status within desirable limits of moisture range of $16.26 \%$ (permanent wilting point) to $27.3 \%$ (field capacity) for $0-15 \mathrm{~cm}$ layer and $17.01 \%$ (permanent wilting point) to $27.83 \%$ (field capacity) for 15-30 cm layer as evident from Fig. 6. In rainfed plots, the crop did not germinate properly and whatever germinated died so no data were recorded for rainfed plots. These figures indicate that command area did not face any moisture stress during total crop period.

\subsection{Performance of crop, horticultural crops and fish}

The yield of different crops (under rainfed and irrigated conditions), horticultural crops and fish are presented in Table 4. It is evident from table that there was significant improvement in crop yields during the monsoon, while the total yield during post-monsoon crops 


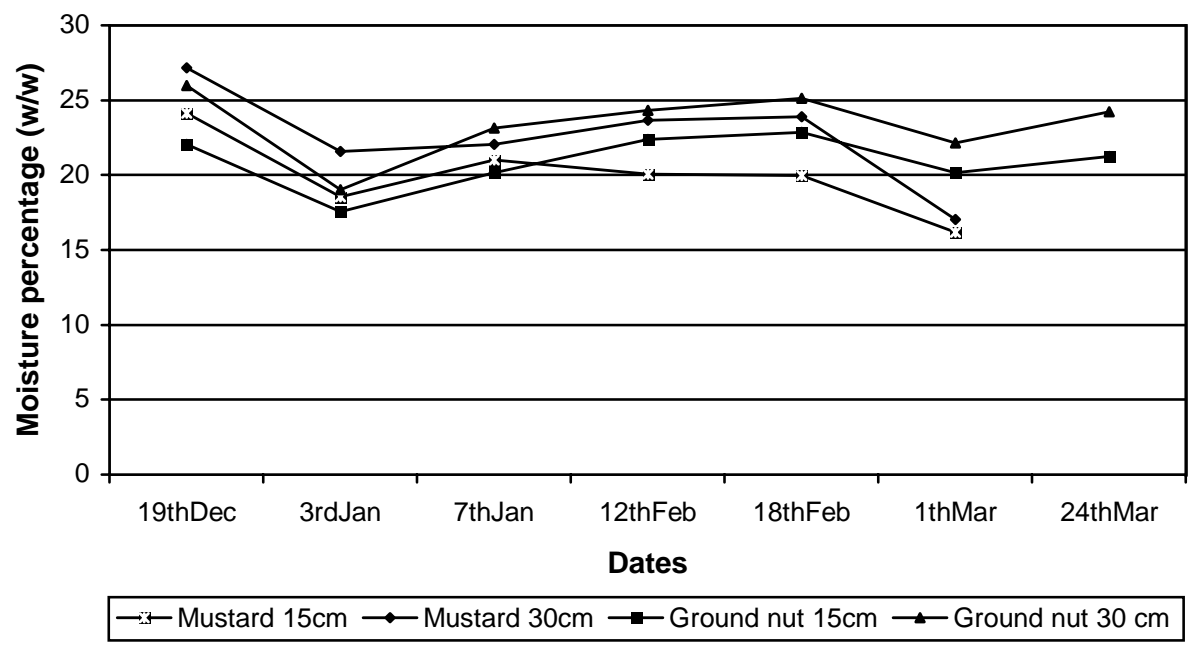

Fig. 6. Moisture data of rabi crops.

were additional as no crop was possible without irrigation. The irrigation water use efficiency (IWUE), i.e. difference between yield under irrigated condition minus yield under rainfed condition divided by depth of irrigation, presented in terms of $\mathrm{kg}$ per ha-mm as well as Rs. per ha-mm which shows that maximum IWUE (kg per ha-mm) is obtained with watermelon followed by mustard, while it was mustard in terms of Rs. per ha-mm.

The productivity of banana, papaya and fish were lower than the normal productivity under best management condition. In case of papaya and banana it was due to poor soil fertility status as the soil on top of the embankment was from $2 \mathrm{~m}$ depth of excavated tank. Although growth rate of fish (Fig. 7) were good under high stocking density, survival rate was poor due to low temperature in winter months, highly turbid environment due to

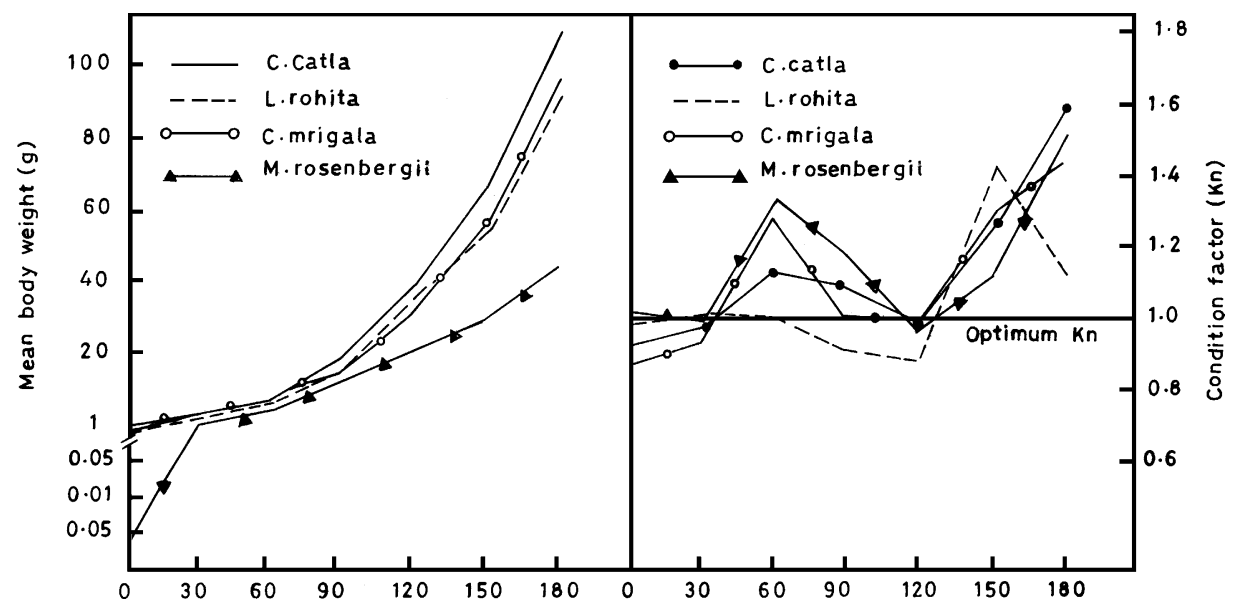

Fig. 7. Comparative growth and condition factor of IMC and prawn in runoff recycling tank. 
Table 4

Performance of crop, horticultural crops and fish under command area and rainfed areas

\begin{tabular}{|c|c|c|c|c|c|c|c|c|c|}
\hline \multirow[t]{3}{*}{ Crop } & \multicolumn{6}{|c|}{ Productivity (t/ha) } & \multirow{3}{*}{$\begin{array}{l}\text { Average additional } \\
\text { production from } \\
\text { command area }\end{array}$} & \multicolumn{2}{|c|}{$\begin{array}{l}\text { Irrigation water use } \\
\text { efficiency }\end{array}$} \\
\hline & \multicolumn{2}{|l|}{ 1998-1999 } & \multicolumn{2}{|l|}{ 1999-2000 } & \multicolumn{2}{|l|}{ 2000-2001 } & & (kg/ha-mm) & (Rs./ha-mm) \\
\hline & Irrigated & Rainfed & Irrigated & Rainfed & Irrigated & Rainfed & & & \\
\hline Rice grain $(0.95 \mathrm{ha})$ & $2.26(100)^{\mathrm{a}}$ & 1.42 & $3.61(145)$ & 2.21 & $3.42(60)$ & 1.90 & $1.22 \mathrm{t}$ & 12.33 & 67.82 \\
\hline $\begin{array}{l}\text { Mustard (0.3 ha in } 1998-1999 \\
\text { and } 0.5 \text { ha in } 1999-2000\end{array}$ & $1.1(120)$ & No yield & $0.85(120)$ & No yield & Not sown & Not sown & $0.39 \mathrm{t}$ & 8.12 & 97.44 \\
\hline Groundnut (0.4 ha) & $1.2(120)$ & No yield & $1.55(225)$ & No yield & $0.80(240)$ & No yield & $0.49 \mathrm{t}$ & 6.07 & 72.82 \\
\hline Watermelon (0.1 ha) & & & & & $4.0(270)$ & No yield & $0.4 \mathrm{t}$ & 14.81 & 29.62 \\
\hline Papaya & \multicolumn{4}{|c|}{ No yield could be obtained due to cyclone } & 13.12 & & $450 \mathrm{~kg}$ & & \\
\hline Banana & \multicolumn{4}{|c|}{ No yield could be obtained due to cyclone } & 9.3 & & 100 dozens & & \\
\hline Fish & 0.63 & & 1.70 & & 1.00 & & $100 \mathrm{~kg}$ & & \\
\hline Prawn & 0.20 & & & & 0.16 & & $16 \mathrm{~kg}$ & & \\
\hline
\end{tabular}

${ }^{\text {a }}$ Figures in parenthesis are irrigation depth in mm, 1 US $\$=$ Rs. $47.40 /-$. 


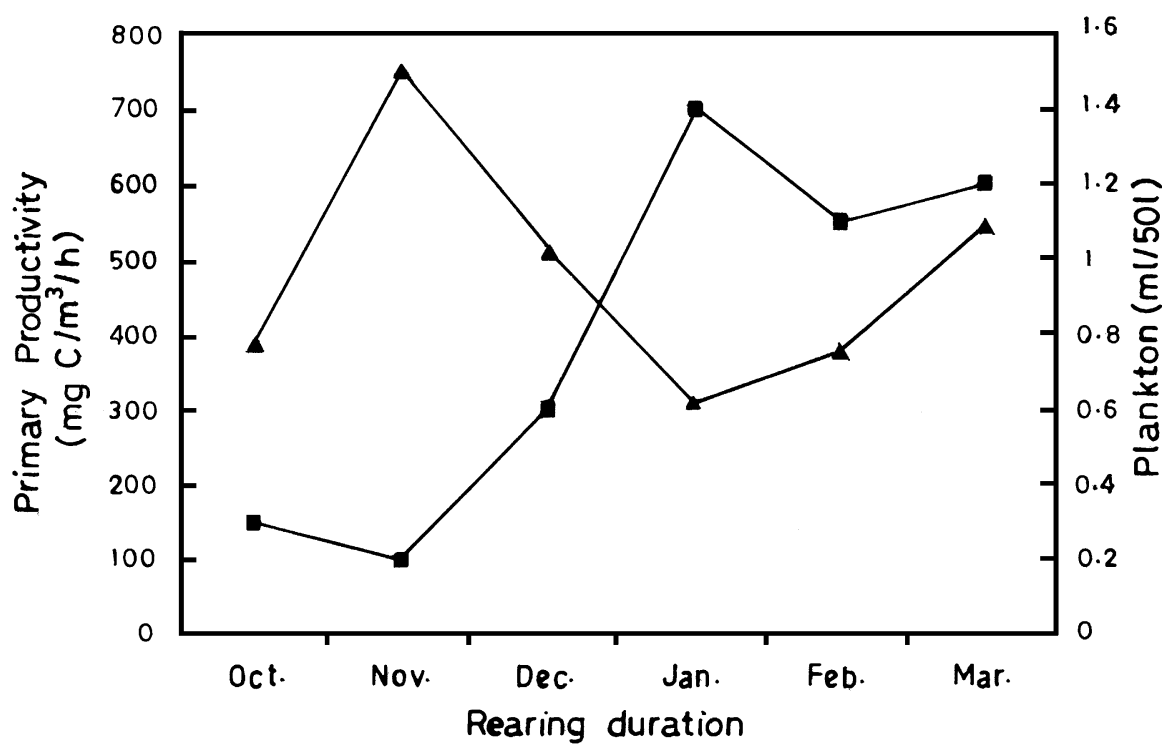

\section{A-Pri Prodn $\rightarrow$ Plankton}

Fig. 8. Primary productivity and plankton content in runoff recycling pond water.

runoff entry, poor availability of natural food in the initial months (Fig. 8), reduced reactive distance of fish due to highly suspended solids, ion leaching $(0.18-0.34 \mathrm{ppm})$ and periodic flushing out of nutrients. During the culture period, faster growth rate was recorded for $C$. catla followed by C. mrigala and L. rohita (Fig. 7), which lends support to the findings of Patra and Ray (1988). Condition factor of fish and prawn was less than $1.0(0.84-0.97)$ at the initial 4 weeks of rearing (monsoon phase) and improved thereafter with gradual improvement in water quality (post-monsoon).

In general, poor growth performance of cultured species takes place at $\mathrm{pH}<6.5$ (Mount, 1973), while higher values of total alkalinity (>90 ppm) and increased plankton density reflect higher productivity of the water body (Mohanty and Mishra, 2003). However, the recorded minimum and maximum range of total alkalinity and $\mathrm{pH}$ ranged between 74-109 ppm and 6.2-8.1, respectively (Fig. 9), due to periodic liming. Maintenance of optimum water quality parameters (Boyd and Pillay, 1985) in monsoon and winter season in runoff recycling pond was difficult as evident from Fig. 9, due to runoff entry and periodic flushing out of nutrients. Various water quality parameters improved as the climate changed gradually from monsoon to winter, towards the latter phase of culture, except in the cases of temperature, dissolved oxygen, nitrite and ammonia. Gradual increase in ammonia and nitrite were attributed by increased level of metabolites and decomposition of unutilized feed while decrease in dissolved oxygen level was attributed to gradual increase in biomass, resulting in higher oxygen consumption.

Plankton has a profound effect on water quality and is the major source of productivity, having a direct relationship with fish production. However, no perceptible trend in total 
○ F FIRST CROP 1998-99

SECOND CROP 1999-2000

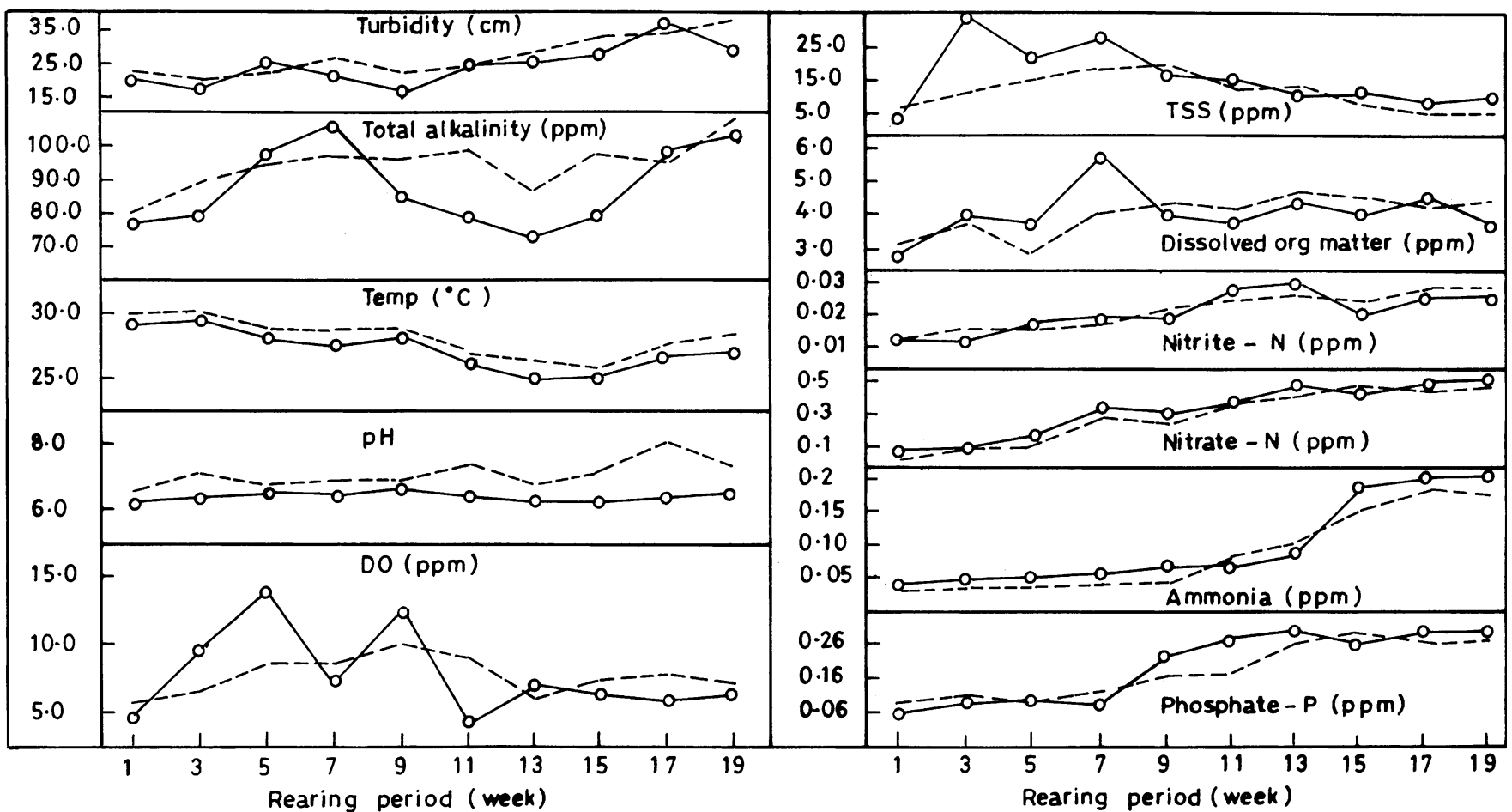

Fig. 9. Fluctuation pattern of hydrological variables in runoff recycling tank during fry-advanced fingerling rearing period. 
plankton density $\left(2.7 \times 10^{2}\right.$ to $10.4 \times 10^{3}$ numbers per liter $)$ and primary productivity was observed in two crops (Fig. 8). Low primary productivity $\left(388 \pm 47 \mathrm{mg} \mathrm{C} / \mathrm{m}^{3} / \mathrm{h}\right.$ ) during winter months was probably due to low temperature and fixation of nutrient ions by suspended soil and clay particles, as well as rich organic matter. Positive indices of electivity were also observed for phytoplankton in monsoon-winter while it was negative for zooplankton during the same period. High degree of satiation $(7.3 \pm 0.4$ to $6.1 \pm 0.2)$ at the initial stage was probably due to relatively low nutritional value of ingested (mud/debris) matter and comparatively less preference to artificial feed, contributed to slow growth of fish at the initial stage of rearing.

\subsection{Economics of the system}

Table 5 presents the additional benefits from the system and additional costs incurred to conduct these activities. As the system size is of field scale, these data are quite realistic and achievable. The total additional gross return from crop activities is Rs. 17,728/- which increase to Rs. 20,128/- if horticulture is added and it further increases to Rs. 24,728/- if fish culture is added. This shows that major part of the return comes from crop activities. However to achieve this additional gross return from crop activities, Rs. 7800/- has to be additionally invested while for other two activities only Rs. 2500/- has to be invested. Thus the return per unit investment is more in allied activities than crop activities. Based on these data, the benefit cost analysis has been carried out for different site conditions (Table 6). It is evident that in all cases, the runoff recycling is beneficial even with irrigation to crop alone. However with multiple uses, the $\mathrm{B}-\mathrm{C}$ ratio rises beyond 3.0. It is also evident from table that additional benefit from allied activities of fish and horticulture ranges from Rs. 4500/- to Rs. $7800 /-$ which is almost equal to the total annual cost of the system. Thus, with multiple use of the water in the tank, the cost of irrigation becomes zero. The data on ground water recharge obtained from simulation (Table 1) shows that in case of unlined tanks, an open dug well can be integrated with the system to harvest back the seeped water and that will further increase the economics of the system. Further, it opens new vistas of employment opportunity spread

Table 5

Economics of the system-additional benefits and costs

\begin{tabular}{|c|c|c|c|c|}
\hline \multirow[t]{2}{*}{ Item } & \multicolumn{2}{|c|}{ Additional annual benefits } & \multicolumn{2}{|l|}{ Additional annual costs } \\
\hline & Average & Gross returns (Rs.) & Item & Cost (Rs.) \\
\hline Rice grain (t) & 1.22 & $6100 /-$ & Cost of water pumped & $2500 /-$ \\
\hline Rice straw (t) & 1.83 & 1098/- & Additional cost of rice cultivation & $500 /-$ \\
\hline Mustard (t) & 0.385 & $3850 /-$ & Cost of rabi cultivation & $4800 /-$ \\
\hline Groundnut $(\mathrm{t})$ & 0.49 & $5880 /-$ & Cost of cultivation of horticultural crops & $500 /-$ \\
\hline Watermelon $(\mathrm{t})$ & 0.4 & $800 /-$ & Cost of fish culture & 2000/- \\
\hline Papaya (kg) & 450 & $1800 /-$ & Return from land occupied by tank & $650 /-$ \\
\hline Banana (number) & 1200 & $600 /-$ & & \\
\hline Fish $(\mathrm{kg})$ & 100 & $3000 /-$ & & \\
\hline Prawn $(\mathrm{kg})$ & 16 & $1600 /-$ & & \\
\hline Total & & $24728 /-$ & & 10950/- \\
\hline
\end{tabular}

1 US $\$=$ Rs. $47.40 /-$. 
Table 6

Benefit cost analysis of runoff recycling systems under different conditions

\begin{tabular}{|c|c|c|c|c|}
\hline $\begin{array}{l}\text { Serial } \\
\text { number }\end{array}$ & Item & $\begin{array}{l}\text { For sites having } \\
\text { seepage loss } \\
<6 \mathrm{~mm} / \text { day }\end{array}$ & $\begin{array}{l}\text { For sites having } \\
\text { seepage loss }>6 \\
\text { but less than } \\
10 \mathrm{~mm} / \text { day }\end{array}$ & $\begin{array}{l}\text { For sites having } \\
\text { seepage loss } \\
>10 \mathrm{~mm} / \text { day, } \\
\text { i.e. lined tanks }\end{array}$ \\
\hline 1 & $\begin{array}{l}\text { Total annual cost of pond for } \\
\text { unit command area of } 1 \text { ha }\end{array}$ & Rs. 4200/- & Rs. 6000/- & Rs. $8000 /-$ \\
\hline 2 & Net return from crop alone & Rs. 9278/- & Rs. 9278/- & Rs. 9278/- \\
\hline 3 & Net return from crop + horti & Rs. 11178/- & Rs. 11178/- & Rs. 11178/- \\
\hline 4 & $\begin{array}{l}\text { Net return from } \\
\text { crop }+ \text { horti }+ \text { fish }\end{array}$ & Rs. 13778/- & Rs. $14778 /{ }^{\mathrm{a}}$ & Rs. $16778 /{ }^{\text {b }}$ \\
\hline 5 & $\mathrm{~B}-\mathrm{C}$ ratio from crop alone & 2.20 & 1.55 & 1.16 \\
\hline 6 & $\mathrm{~B}-\mathrm{C}$ ratio from crop + horti & 2.66 & 1.86 & 1.40 \\
\hline 7 & $\begin{array}{l}\text { B-C ratio from } \\
\text { crop }+ \text { horti }+ \text { fish }\end{array}$ & 3.28 & 2.46 & 2.09 \\
\hline 8 & $\begin{array}{l}\text { Expected B-C ratio from } \\
\text { crop }+ \text { horti }+ \text { fish }+ \text { duckery }\end{array}$ & $>3.50$ & 3.00 (approximately) & 2.50 (approximately) \\
\hline 9 & $\begin{array}{l}\text { Ground water recharge from } \\
\text { catchment area, tank and } \\
\text { command area for unit system } \\
\text { having } 1 \text { ha command area } \\
\text { (estimated from simulation) }\end{array}$ & $3000 \mathrm{~m}^{3}$ & $4000 \mathrm{~m}^{3}$ & $2500 \mathrm{~m}^{3}$ \\
\hline
\end{tabular}

1 US $\$=$ Rs. $47.40 /$ -

${ }^{\text {a }}$ Fish production will be more as the water area will be larger.

${ }^{\mathrm{b}}$ Fish productivity will be higher as the water will be less turbid.

over the year reducing the seasonal variation of employment availability. Thus the system has a potential of transforming subsistence agriculture to commercial agriculture.

\section{Conclusion}

The field evaluation of water harvesting based irrigation system designed on the basis of methodology developed shows that the methodology is correct for designing the system. The water harvesting based irrigation system is capable of fulfilling the irrigation need of a transplanted rice based crop rotation in high rainfall areas. Use of harvested water in both seasons increases the efficiency of the system which can be measured in terms of water yield-storage capacity ratio. Although the system has a favorable benefit cost ratio with crop alone, its multiple use for horticulture, fisheries and duckery makes it very profitable proposition. This assumes importance in the region where the rainfed farmers survive on subsistence agriculture. This system has a potential of transforming this subsistence agriculture to commercial agriculture. It creates more employment opportunities all-round the year and therefore is sustainable for a small farmer.

\section{References}

APHA, 1989. Standard Methods for Examination of Water and Waste Water, 17th ed. American Public Health Association, Washington, DC, USA, p. 1647. 
Bhatnagar, P.R., Srivastava, R.C., Bhatnagar, V.K., 1996. Management of runoff stored in small tanks for transplanted rice production in mid hills of N-W Himalayas. Agric. Water Manage. 30, 107-118.

Biswas, K.P., 1993. Fisheries Manual. Bhagbat Press and Publishers, Cuttuck, India, p. 436.

Boyd, C.E., Pillay, V.K., 1985. Water Quality Management in Aquaculture. Special Publication No. 22, CMFRI (ICAR), Cochin, India, p. 96.

Mohanty, R.K., 1999. Growth performance of Penaeus monodon at different stocking density. J. Inland Fish. Soc. India 31 (1), 53-59.

Mohanty, R.K., 2000. Primary productivity and seasonal plankton abundance in artificially controlled semi-intensive shrimp pond. J. Indian Soc. Coastal Agric. Resh. 18 (1), 40-46.

Mohanty, R.K., Mishra, A., 2003. Successful rice-fish integrated farming adopting rainwater conservation measures. Fishing Chimes 22 (10/11), 97-99.

Mount, D.I., 1973. Chronic exposure of low pH on fathead minnow's survival, growth and reproduction. Water Res. 7, 987-993.

Patra, B.C., Ray, A.K., 1988. Observations on the influence of three organic manures on the growth and yield of Indian major carps under pond culture. J. Inland Fish. Soc. India 20 (2), 61-63.

Sehgal, J.L., Mondal, D.K., Mandal, C., Vadivelu, S., 1992. India's Agro-Ecological Regions, 2nd ed. Technical Bulletin 24, BSSLUP, Nagpur, India.

Singh, R., Kundu, D.K., Das, M., 2000. Characterization of Soils at Deras Farm, Mendhasal, in Khurda District. WTCER Bhubaneswar Publication.

Spataru, P., Gophen, M., 1986. Food consumption of Tristramella simonis (Gunther, 1864) in lake Kinneret (Israel). J. Aquat. Trop. 1, 111-117.

Srivastava, R.C., 1996a. A methodology for optimizing design of integrated tank irrigation system. J. Water Resour. Plann. Manage. 122 (6), 394-402.

Srivastava, R.C., 1996b. Design of runoff recycling irrigation system for rice cultivation. J. Irrigation Drain. Eng. (ASCE) 122 (6), 331-335.

Srivastava, R.C., 2001. A methodology for design of water harvesting system in high rainfall areas. Agric. Water Manage. 47 (1), 37-53.

Srivastava, R.C., Panda, R.K., 1998. Potential and prospects of runoff recycling based irrigation system in plateau region of eastern India. Indian J. Soil Conserv. 26 (2), 104-108.

WTCER, 2001. Report of Consultancy Project on Comprehensive Water Resource Development Planning for Two Gram Panchayats of Kalahandi and Raygada of Orissa. Water Technology Centre for Eastern Region (ICAR), India, p. 50. 